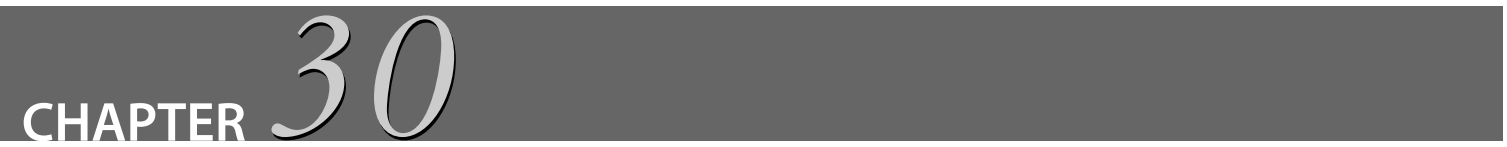

\title{
The Behavior of International Stock Market Excess Returns in an Increasingly Integrated World*
}

\section{Michael Donadelli}

Department of Economics and Finance, LUISS Guido Carli, Rome, Italy

Center of Excellence SAFE, Goethe, University Frankfurt, Germany

\section{INTRODUCTION}

There is an extensive literature on empirical finance that studies the behavior of international stock markets. Common empirical regularities are as follows: (i) emerging stock market average excess returns are higher than advanced stock market average excess returns; (ii) emerging stock markets are characterized by higher volatility as well as by higher instability; (iii) international stock markets are increasingly integrated; and (iv) equity market liberalizations reduced the cost of capital (i.e., expected returns). However, most of these findings have been obtained in static context using stock market country indexes in a "pre-2000 world".

This chapter has two main goals. First, it studies the behavior of stock market country indexes as well as the behavior of stock market sector indexes for a large number of emerging and advanced economies. Second, using a robust measure of financial integration, it examines the impact of the global integration process on international stock market excess returns. Differently from previous empirical works, it adopts an updated dataset which allows for a "post-2000 world" analysis. Many investors regard the past decade as an unusual one for international stock market returns. As suggested by Hammond and Leibowitz (2011), investors' view might be based on huge changes in equity market behavior, including much lower than average returns (in advanced economies), much higher than average returns (in emerging economies), much higher volatility, two of the biggest bubbles in stock market history, and rising cross-asset, cross-country, cross-sector, and intra-sector correlations.

The results of this chapter are based on recent empirical works that examine the comovement between international stock market excess returns impact of the de jure and the de facto integration on emerging and advanced stock market excess returns. ${ }^{1}$ While

\footnotetext{
*All errors are the author's responsibility.

${ }^{1}$ See Bekaert et al. (2011), Donadelli and Prosperi (2012), and Donadelli (2013a,b).
} 
Grootveld and Salomons (2003) examine the behavior of the Equity Risk Premium (ERP), this chapter focuses on the excess returns. ${ }^{2}$

Based on data availability, few works have been devoted to examine the behavior of emerging stock market prices in the pre-1990 era. As data on emerging stock market prices started to be available (i.e., early 1990s), the financial literature started to focus on emerging stock market performances as well as on the predictability of emerging stock market excess returns. Early studies find that local risk factors play a crucial role in explaining emerging excess returns' patterns (i.e., global risk factors have love explanatory power). It turns out that standard asset pricing linear models, such as the world CAPM, do a poor job in explaining variation in emerging excess returns. In contrast, they do a good job in explaining variation in advanced stock market excess returns (Donadelli and Prosperi, 2012). Following equity market liberalizations across emerging economies, the literature started to be interested in examining the impact of liberalized markets on emerging stock prices. Most recent studies show that emerging stock prices are influenced by global risk sources. Reduction ad absurdum, under specific time-horizons, the onefactor model is enough to explain variation in emerging stock market excess returns. Nevertheless, Donadelli and Prosperi (2012) and Donadelli (2013a,b) show that model's validity is rarely preserved as well as heavily sample-sensitive. If the last decade is analyzed, in a country-by-country and sector-by-sector contexts, they find that the intercept (or Jensen's alpha or unexpected average excess returns) is positive and statistically different from zero in several emerging stock markets. It turns out that models' validity is also a dynamic concept. A large part of pre-2000 and early 2000s studies argue that stock market liberalization may reduce the liberalizing country's cost of equity capital by allowing for international risk sharing (Stulz, 1999a,b). As a consequence, if the market learns that a stock market liberalization is going to occur, then a country's equity price index should increase (Henry, 2000). As discussed in Donadelli (2013a,b), many studies on emerging stock market liberalizations are developed in a static context. In addition, a large number of empirical works employ stock market country indexes and do not consider sector indexes. While the impact of the de jure integration has been largely examined, the real effects of the de facto integration on international stock market prices have been rarely discussed. In contrast to early studies, this chapter examines the behavior of international stock market excess returns as well as the impact of the de facto integration on stock market indexes, both at the country and sector level, in a pure time-varying context. The key empirical findings of this chapter can be summarized as follows: (i) emerging stock market country and sector indexes (i.e., excess returns) have a strong time-varying component; (ii) during the last 10 years advanced and emerging realized average excess returns (i.e., international stock market country and sector indexes) have largely increased, and emerging stock markets have became increasingly integrated; (iii) existing empirical

\footnotetext{
${ }^{2}$ The ERP is a long-term concept, and it is often associated to the resolution of the well-known Equity Premium puzzle (Mehra and Prescott, 1985).
} 
findings that examine the impact of financial market liberalizations on emerging stock market prices have been heavily influenced by domestic shocks, such as the Mexican crisis (1994), the Asian financial crisis (1997), the Russian default (1998), the Argentine economic crisis (2001), the $9 / 11$ terrorist attacks (2001), and the subprime crisis $(2008)^{3}$; (iv) there exists a delay between de jure and de facto integration; (v) the real (i.e., tradeto-GDP ratio) and financial (i.e., the $\bar{R}^{2}$ of a multi-(artificial) factor model) integration processes follow a similar path; and (vi) the intercept (or unexpected excess returns) across emerging stock markets is significantly higher than across advanced (or US) stock markets (i.e., standard linear-factor models do not fully explain variation in emerging stock market excess returns).

\section{SUMMARY STATISTICS AND PRELIMINARY ANALYSIS}

This section examines the performance of international stock market indexes and degree of co-movement between international stock market excess returns in a dynamic context. ${ }^{4}$ In contrast to existing empirical studies, which focus on national stock market indexes, this chapter examines both country and sector indexes. ${ }^{5}$ The analysis is conducted over different time-horizons and for different countries/regions.

\subsection{Stock Market Country Indexes}

Stock market country indexes are represented by the Morgan Stanley Capital International Total Return Indexes (MSCI TRIs). As standard in the literature, all indexes are denominated in US dollars. Returns are computed from MSCI TRIs for 28 emerging and 7 advanced stock markets, as well as for 7 regions. ${ }^{6}$ Formally:

$$
R_{n, t}=\frac{C I_{n, t}}{C I_{n, t-1}}-1,
$$

where $R_{n, t}$ is the return of country/region $n$ at time $t, C_{t}$ represents the MSCI TRI in country/region $n$ at time $t$. Excess returns are then computed by subtracting from Eq. (1) the one-month T-bill rate. ${ }^{7}$ Data are monthly and run from January 1988 (or

\footnotetext{
${ }^{3}$ For a detailed discussion on emerging financial crises, see Joyce (2011).

${ }^{4}$ A similar analysis can be found in Donadelli and Prosperi (2012), Grootveld and Salomons (2003), and Harvey (1995a,b), among others.

5 Throughout the chapter the terms "National (industrial) stock market excess returns" and "stock market country (sector) excess returns will be used interchangeably".

6 Datastream mnemonic for each country contains the following designations: "TRI" (i.e., reinvested dividends) and “ U\$” (i.e., the original local currency equity index is converted in US dollars with the Datastream exchange rate conversion facility). The coverage in time and across countries is limited by the availability of all data required. Data starting point limits: Colombia, Peru, Poland, China, India, Pakistan, Sri Lanka, and South Africa (from January 93); Czech Republic, Hungary, Russia, and Egypt (from January 95); Kenya and Nigeria (from June 02); Morocco and Tunisia (from June 04).

7 The one-month T-bill rate series is from the Kenneth French Data Library.
} 
Table 1 List of employed MSCI TRIs.

\begin{tabular}{|c|c|c|c|c|c|}
\hline \multirow{2}{*}{$\frac{\text { Developed countries }}{\text { Advanced }}$} & \multicolumn{5}{|c|}{ Emerging countries } \\
\hline & $\begin{array}{l}\text { Latin } \\
\text { America }\end{array}$ & $\begin{array}{l}\text { Eastern } \\
\text { Europe }\end{array}$ & Asia & $\begin{array}{l}\text { Sub-Saharan } \\
\text { Africa }\end{array}$ & $\begin{array}{l}\text { North African } \\
\text { and ME }\end{array}$ \\
\hline $\begin{array}{l}\text { Canada } \\
\text { France } \\
\text { Germany } \\
\text { Italy } \\
\text { Japan } \\
\text { United Kingdom } \\
\text { United States }\end{array}$ & $\begin{array}{l}\text { Argentina } \\
\text { Brazil } \\
\text { Chile } \\
\text { Colombia } \\
\text { Mexico } \\
\text { Perù }\end{array}$ & $\begin{array}{l}\text { Czech Republic } \\
\text { Hungary } \\
\text { Poland } \\
\text { Russia } \\
\text { Turkey }\end{array}$ & $\begin{array}{l}\text { China } \\
\text { India } \\
\text { Indonesia } \\
\text { Korea } \\
\text { Malaysia } \\
\text { Pakistan } \\
\text { Philippines } \\
\text { Sri Lanka } \\
\text { Taiwan } \\
\text { Thailand }\end{array}$ & $\begin{array}{l}\text { Kenya } \\
\text { Nigeria } \\
\text { South Africa }\end{array}$ & $\begin{array}{l}\text { Egypt } \\
\text { Jordan } \\
\text { Morocco } \\
\text { Tunisia }\end{array}$ \\
\hline
\end{tabular}

Source: Datastream.

later) to December 2011. The full list of employed stock market country indexes, ordered by geographic area, is presented in Table 1 .

Monthly summary statistics for the international stock market excess returns are reported in Table 2. Mean, standard deviation, minimum, maximum, and median values are all expressed in percentage points and computed over the period January 1988December 2011. The last two lines of Table 2 report the average values of the monthly statistics across the 28 emerging markets and across the 7 advanced markets.

The mean values confirm that emerging stock markets tend to deliver higher average excess returns than advanced markets (i.e., $15.6 \%$ vs $5.04 \%$, on annual basis), as well as higher volatility (i.e., $127.92 \%$ vs $71.76 \%$, on annual basis). As reported in Bekaert et al. (1998), developed markets tend to display negative skewness over the period January 1988-December 2011. The skewness is negative in 5 out of 7 advanced markets. A similar result is obtained by Grootveld and Salomons (2003), Donadelli and Prosperi (2012). For example, Grootveld and Salomons (2003) find that 5 out of 7 developed stock markets display negative skewness over the period January 1976-December 2001. In contrast, they show that most emerging stock markets display positive skewness. For a shorter sample (i.e., January 2000-December 2010), Donadelli and Prosperi (2012) observe that the skewness is negative in 13 out of 13 developed stock markets. As pointed out by Donadelli (2013a), the result is clearly state-contingent, that is, it strongly depends on macroeconomic scenarios.

Table 3 reports the monthly summary statistics for the excess return of seven regions (i.e., Latin America, Eastern Europe, Asia, Sub-Saharan, North African and Middle East, Emerging, and Advanced). Regional excess returns are obtained by forming equal-, 
Table 2 Stock market country excess returns: summary statistics (monthly). Sample: January 1988 (or later)-December 2011.

\begin{tabular}{|c|c|c|c|c|c|c|c|c|}
\hline Country & Mean & Std Dev. & ShR & Max & Min & Median & Kurtosis & Skewness \\
\hline \multicolumn{9}{|c|}{ Emerging economies } \\
\hline Argentina & 2.15 & 15.85 & 0.14 & 95.05 & -58.40 & 1.05 & 9.46 & 1.66 \\
\hline Brazil & 2.40 & 15.04 & 0.16 & 79.95 & -67.19 & 2.28 & 4.85 & 0.25 \\
\hline Chile & 1.41 & 7.25 & 0.19 & 21.65 & -33.04 & 1.44 & 2.33 & -0.46 \\
\hline Colombia & 1.58 & 9.75 & 0.16 & 30.30 & -40.85 & 1.66 & 1.62 & -0.24 \\
\hline Mexico & 1.76 & 9.55 & 0.18 & 28.47 & -47.64 & 2.21 & 3.13 & -0.79 \\
\hline Perú & 1.70 & 9.77 & 0.17 & 37.58 & -51.56 & 2.18 & 4.96 & -0.45 \\
\hline Czech Rep. & 1.27 & 9.53 & 0.13 & 35.83 & -51.77 & 1.06 & 5.37 & -0.76 \\
\hline Hungary & 1.51 & 12.00 & 0.13 & 45.74 & -62.24 & 1.76 & 4.82 & -0.56 \\
\hline Poland & 1.77 & 14.40 & 0.12 & 117.07 & -52.74 & 1.31 & 18.23 & 2.10 \\
\hline Russia & 2.34 & 16.41 & 0.14 & 60.69 & -61.07 & 2.30 & 2.63 & -0.03 \\
\hline Turkey & 1.90 & 16.71 & 0.11 & 72.61 & -49.38 & 1.34 & 2.07 & 0.54 \\
\hline China & 0.28 & 10.78 & 0.03 & 46.44 & -43.06 & 0.24 & 2.87 & 0.33 \\
\hline India & 0.91 & 8.99 & 0.10 & 32.46 & -40.67 & 1.39 & 1.64 & -0.24 \\
\hline Indonesia & 1.69 & 14.74 & 0.11 & 93.79 & -45.78 & 1.03 & 9.52 & 1.57 \\
\hline Korea & 0.92 & 11.20 & 0.08 & 59.72 & -47.15 & 0.11 & 3.92 & 0.43 \\
\hline Malaysia & 0.74 & 8.05 & 0.09 & 38.57 & -30.61 & 1.15 & 3.53 & -0.02 \\
\hline Pakistan & 0.84 & 11.27 & 0.07 & 36.01 & -38.13 & 0.05 & 1.68 & -0.05 \\
\hline Philippines & 0.77 & 9.66 & 0.08 & 43.07 & -36.82 & 0.72 & 2.35 & 0.22 \\
\hline Sri Lanka & 0.80 & 10.59 & 0.08 & 60.15 & -25.58 & -0.16 & 6.74 & 1.50 \\
\hline Taiwan & 0.72 & 10.62 & 0.07 & 46.21 & -34.33 & 0.70 & 1.63 & 0.25 \\
\hline Thailand & 1.03 & 11.47 & 0.09 & 60.73 & -41.97 & 1.27 & 4.02 & 0.32 \\
\hline Kenya & 2.05 & 9.29 & 0.22 & 24.44 & -33.93 & 1.81 & 1.68 & -0.42 \\
\hline Nigeria & 1.17 & 9.97 & 0.12 & 41.70 & -37.37 & 0.46 & 3.15 & 0.14 \\
\hline South Africa & 1.12 & 8.43 & 0.13 & 33.77 & -44.81 & 1.29 & 4.73 & -0.75 \\
\hline Egypt & 1.40 & 9.68 & 0.14 & 37.17 & -33.37 & 0.65 & 1.45 & 0.41 \\
\hline Jordan & 0.07 & 5.49 & 0.01 & 22.39 & -24.88 & -0.43 & 2.79 & -0.05 \\
\hline Morocco & 1.15 & 6.40 & 0.18 & 19.49 & -23.84 & 0.72 & 2.37 & -0.42 \\
\hline Tunisia & 1.08 & 5.72 & 0.19 & 21.23 & -20.94 & 0.92 & 3.54 & 0.03 \\
\hline \multicolumn{9}{|c|}{ Advanced economies } \\
\hline France & 0.56 & 6.10 & 0.09 & 20.57 & -22.26 & 0.92 & 0.75 & -0.28 \\
\hline Germany & 0.57 & 6.59 & 0.09 & 19.62 & -22.83 & 1.31 & 1.02 & -0.43 \\
\hline Italy & 0.26 & 7.29 & 0.04 & 27.29 & -23.54 & 0.24 & 0.98 & 0.10 \\
\hline Japan & -0.12 & 6.79 & -0.02 & 23.58 & -23.99 & 0.14 & 0.75 & 0.04 \\
\hline United Kingdom & 0.44 & 5.15 & 0.09 & 17.23 & -23.24 & 0.53 & 1.64 & -0.27 \\
\hline United States & 0.56 & 4.34 & 0.13 & 13.50 & -20.07 & 1.05 & 1.90 & -0.63 \\
\hline Canada & 0.65 & 5.61 & 0.12 & 17.15 & -34.22 & 1.06 & 5.44 & -0.94 \\
\hline Avg. (Emerg) & 1.30 & 10.66 & 0.12 & 47.94 & -42.11 & 1.09 & 4.18 & 0.16 \\
\hline Avg. (Adv) & 0.42 & 5.98 & 0.08 & 19.85 & -24.31 & 0.75 & 1.78 & -0.35 \\
\hline
\end{tabular}

Source: Based on Donadelli (2013a). 
Table 3 Regional stock market excess returns: summary statistics (monthly). Sample: January 1988 (or later)-December 2011.

\begin{tabular}{|c|c|c|c|c|c|c|c|}
\hline & $\begin{array}{c}\text { Latin } \\
\text { America }\end{array}$ & $\begin{array}{l}\text { Eastern } \\
\text { Europe }\end{array}$ & $\begin{array}{c}\text { Asia } \\
\text { Far-East }\end{array}$ & $\begin{array}{l}\text { Sub-Saharan } \\
\text { Africa }\end{array}$ & $\begin{array}{l}\text { North African and } \\
\text { Middle East }\end{array}$ & $\begin{array}{l}\text { Emerging } \\
\text { (All) }\end{array}$ & $\begin{array}{l}\text { Advanced } \\
\quad \text { (G7) }\end{array}$ \\
\hline \multicolumn{8}{|c|}{ Equally weighted portfolios } \\
\hline Mean & 2.04 & 1.91 & 0.95 & 1.10 & 0.51 & 1.41 & 0.42 \\
\hline Std dev. & 8.37 & 13.55 & 7.07 & 7.36 & 5.13 & 6.44 & 4.91 \\
\hline ShR & 0.24 & 0.14 & 0.13 & 0.15 & 0.10 & 0.22 & 0.08 \\
\hline $\operatorname{Max}$ & 27.74 & 72.61 & 21.60 & 21.16 & 18.20 & 19.75 & 17.09 \\
\hline Min & -47.42 & -55.44 & -33.39 & -30.90 & -25.76 & -38.98 & -24.31 \\
\hline Median & 1.85 & 1.80 & 1.09 & 1.51 & 0.31 & 2.06 & 0.83 \\
\hline Kurtosis & 4.60 & 4.87 & 2.55 & 3.03 & 2.95 & 5.93 & 2.46 \\
\hline Skewness & -0.69 & 0.72 & -0.50 & -0.77 & -0.29 & -1.16 & -0.56 \\
\hline \multicolumn{8}{|c|}{ GDP-weighted portfolios } \\
\hline Mean & 2.06 & 1.84 & 0.84 & 0.97 & 0.94 & 1.33 & 0.37 \\
\hline Std dev. & 10.28 & 14.27 & 7.94 & 7.55 & 7.30 & 7.28 & 4.54 \\
\hline ShR & 0.20 & 0.13 & 0.11 & 0.13 & 0.13 & 0.18 & 0.08 \\
\hline Max & 49.27 & 72.61 & 27.70 & 26.06 & 34.76 & 23.64 & 15.66 \\
\hline Min & -49.80 & -56.38 & -41.21 & -33.51 & -28.22 & -40.55 & -22.30 \\
\hline Median & 2.35 & 0.90 & 1.03 & 1.67 & 0.05 & 1.51 & 0.78 \\
\hline Kurtosis & 4.20 & 3.43 & 2.91 & 3.29 & 3.00 & 4.21 & 2.34 \\
\hline Skewness & -0.34 & 0.48 & -0.41 & -0.68 & 0.67 & -0.73 & -0.59 \\
\hline \multicolumn{8}{|c|}{ Trade-weighted portfolios } \\
\hline Mean & 1.97 & 1.94 & 0.81 & 0.98 & 0.95 & 1.23 & 0.42 \\
\hline Std dev. & 8.90 & 13.96 & 7.96 & 7.52 & 5.76 & 7.45 & 4.77 \\
\hline ShR & 0.22 & 0.14 & 0.10 & 0.13 & 0.17 & 0.16 & 0.09 \\
\hline Max & 31.18 & 72.61 & 25.79 & 26.43 & 22.83 & 20.95 & 16.41 \\
\hline Min & -48.49 & -56.23 & -40.36 & -31.16 & -25.47 & -43.99 & -23.05 \\
\hline Median & 2.33 & 1.26 & 1.30 & 1.54 & 0.50 & 1.87 & 0.88 \\
\hline Kurtosis & 4.04 & 3.98 & 2.84 & 3.04 & 2.39 & 5.10 & 2.32 \\
\hline Skewness & -0.86 & 0.56 & -0.42 & -0.64 & 0.13 & -1.03 & -0.61 \\
\hline
\end{tabular}

Source: Based on Donadelli (2013a).

GDP-, and trade-weighted regional MSCI TRIs (i.e., equal-, GDP-, and trade-weighted portfolios). ${ }^{8}$ Mean, standard deviation, minimum, maximum, and median values are expressed in percentage points. Monthly statistics, at the region level, confirm that emerging markets tend to generate higher average excess returns (i.e., ERP) and display higher volatility than developed markets. Results across equal-, GDP, and trade-weighted portfolios are almost identical. In addition, values in Table 3 shows that the average risk premium

${ }^{8}$ For a detailed discussion on the portfolio construction methodology, see Donadelli (2013a). 
per unit of risk (i.e., Sharpe ratios) in the advanced world is heavily lower than the average risk premium per unit of risk in the emerging world (i.e., 0.08 vs $0.22,0.08$ vs 0.18 , and 0.09 vs 0.16 for the equal-, GDP-, and trade-weighted portfolios, respectively). Statistics confirm also the presence of asymmetry. In fact, the skewness is negative in 6 out of 7 equal-weighted portfolios, and in 5 out of 7 GDP- and trade-weighted portfolios. Such results are heavily driven by the employed sample, which represents a period including many emerging market crises (e.g., Mexican crisis, 1994; Asian crisis, 1997, the 9/11 terrorist attack, and the recent subprime crisis).

\subsection{Stock Market Sector Indexes}

Stock market sector indexes are represented by Datastream Global Equity Indexes (DGEI). The database breaks down into six levels. Level 1 is the market index, this covers all the sectors in each region or country. Level 2 divides the market into 10 industries and covers all the sectors within each group in each region or country. Levels 3-6 subdivide the level 2 classifications into sector classifications in increasing detail. To have a sufficient number of firms listed in each sector index, it is worth using the 10 sector indexes of level 2 (i.e., Basic Materials, Consumer Goods, Consumer Services, Financials, Healthcare, Industrials, Oil \& Gas, Telecommunications, Technology, and Utilities). All series are monthly total return indexes denominated in US dollars and run from January 1994 (or later) to June 2012. The stock market sector excess returns are computed as follows:

$$
E \times R_{i, t}^{n}=\left(\frac{S I_{i, t}^{n}}{S I_{i, t-1}^{n}}-1\right)-R_{f, t},
$$

where $E x R_{i, t}$ is the excess return of industry $i$ in country/region $n$ at time $t, S I_{t}$ is the DGEI of industry $i$ in country/region $n$ at time $t$, and $R_{f, t}$ is the one-month Treasury bill.

Table 4 reports the mean, standard deviation, and Sharpe ratio values for the 10 sectors. Statistics are provided for 23 emerging stock markets and, for comparison purposes, for the US stock market. For each national stock market, the first two lines report the mean and standard deviation values, respectively. Line 3 reports the Sharpe ratios. Line 4 provides the spread between the average emerging and US stock excess returns. The spread is computed as follows:

$$
\operatorname{Spread}_{i}^{E M}=E x R_{i, \text { avg }}^{U S}-E x R_{i, \text { avg }}^{E M},
$$

where $E x R_{i, \text { avg }}^{U S}$ is the average excess returns of industry $i$ in the US market, and $E x R_{i, \text { avg }}^{E M}$ is the average excess returns of industry $i$ in one of the analyzed emerging stock markets. Values are monthly and expressed in percentage points. The sample goes from January 1995 (or later) to June 2012.

At the sector level, we confirm that emerging markets tend to perform better than advanced markets. Statistics show that the sector-by-sector spread is mostly positive. Focusing on emerging average statistics, the spread ranges from a minimum of $0.04 \%$ 
Table 4 International stock market sector excess returns: summary statistics (monthly). Statistics are computed for 10 different sectors in 23 different countries. Emerging: emerging average sector-based statistics (i.e., mean, standard deviation, sharpe ratios, and spread are averaged over 22 emerging countries). Sample: January 1995 (or later)-June 2012.

\begin{tabular}{|c|c|c|c|c|c|c|c|c|c|c|}
\hline Country & OilGas & BasMats & ConsGds & ConsSvs & Ind. & $\mathrm{HC}$ & Financ. & Telec. & Tech. & Utilit. \\
\hline \multirow[t]{3}{*}{ US } & 0.92 & 0.76 & 0.50 & 0.64 & 0.81 & 0.66 & 0.64 & 0.40 & 0.94 & 0.55 \\
\hline & 6.30 & 7.61 & 5.66 & 5.87 & 6.42 & 4.70 & 7.03 & 6.26 & 8.45 & 4.82 \\
\hline & 0.15 & 0.10 & 0.09 & 0.11 & 0.13 & 0.14 & 0.09 & 0.06 & 0.11 & 0.11 \\
\hline \multirow[t]{4}{*}{ Arg } & 0.42 & 0.96 & 0.06 & 0.96 & 0.77 & $\mathrm{n} / \mathrm{a}$ & 0.54 & 0.41 & $\mathrm{n} / \mathrm{a}$ & -0.11 \\
\hline & 12.85 & 12.13 & 15.12 & 12.41 & 12.37 & $\mathrm{n} / \mathrm{a}$ & 13.00 & 13.47 & $\mathrm{n} / \mathrm{a}$ & 10.91 \\
\hline & 0.03 & 0.08 & 0.00 & 0.08 & 0.06 & $\mathrm{n} / \mathrm{a}$ & 0.04 & 0.03 & $\mathrm{n} / \mathrm{a}$ & -0.01 \\
\hline & -0.51 & 0.21 & -0.44 & 0.32 & -0.04 & $\mathrm{n} / \mathrm{a}$ & -0.10 & 0.01 & $\mathrm{n} / \mathrm{a}$ & -0.66 \\
\hline \multirow{4}{*}{ Brazil } & 1.87 & 1.27 & 1.69 & 2.12 & 1.46 & 0.92 & 1.08 & 0.82 & 2.95 & 0.83 \\
\hline & 12.82 & 11.91 & 10.24 & 12.82 & 10.69 & 13.77 & 10.64 & 11.43 & 11.89 & 11.80 \\
\hline & 0.15 & 0.11 & 0.16 & 0.17 & 0.14 & 0.07 & 0.10 & 0.07 & 0.25 & 0.07 \\
\hline & 0.94 & 0.51 & 1.19 & 1.48 & 0.66 & 0.26 & 0.44 & 0.42 & 2.02 & 0.28 \\
\hline \multirow[t]{4}{*}{ Chile } & 0.69 & 0.95 & 0.74 & 1.14 & 0.51 & 1.20 & 0.76 & 0.50 & 1.69 & 0.45 \\
\hline & 7.59 & 8.03 & 7.15 & 8.35 & 8.11 & 9.54 & 6.12 & 8.74 & 8.66 & 6.91 \\
\hline & 0.09 & 0.12 & 0.10 & 0.14 & 0.06 & 0.13 & 0.12 & 0.06 & 0.20 & 0.07 \\
\hline & -0.23 & 0.19 & 0.24 & 0.50 & -0.30 & 0.53 & 0.13 & 0.10 & 0.76 & -0.10 \\
\hline \multirow[t]{4}{*}{ China } & 1.55 & 1.84 & 2.16 & 0.87 & 1.52 & 4.78 & 1.40 & 1.32 & 0.88 & 1.39 \\
\hline & 13.57 & 15.21 & 14.84 & 13.09 & 14.33 & 14.36 & 11.89 & 10.45 & 10.34 & 10.88 \\
\hline & 0.11 & 0.12 & 0.15 & 0.07 & 0.11 & 0.33 & 0.12 & 0.13 & 0.09 & 0.13 \\
\hline & 0.63 & 1.08 & 1.66 & 0.23 & 0.71 & 4.12 & 0.77 & 0.92 & -0.06 & 0.83 \\
\hline \multirow[t]{4}{*}{ CzRep } & 1.47 & 0.58 & 0.79 & 1.44 & 1.00 & $\mathrm{n} / \mathrm{a}$ & 1.53 & 0.98 & $\mathrm{n} / \mathrm{a}$ & 1.41 \\
\hline & 1.46 & 0.58 & 0.75 & 1.44 & 0.95 & $\mathrm{n} / \mathrm{a}$ & 1.54 & 0.98 & $\mathrm{n} / \mathrm{a}$ & 1.41 \\
\hline & 1.01 & 0.99 & 1.06 & 1.00 & 1.05 & $\mathrm{n} / \mathrm{a}$ & 0.99 & 1.00 & $\mathrm{n} / \mathrm{a}$ & 1.00 \\
\hline & 0.55 & -0.18 & 0.29 & 0.80 & 0.19 & $\mathrm{n} / \mathrm{a}$ & 0.89 & 0.58 & $\mathrm{n} / \mathrm{a}$ & 0.85 \\
\hline \multirow[t]{4}{*}{ HK } & 3.09 & 0.50 & 1.17 & 0.45 & 0.72 & $\mathrm{n} / \mathrm{a}$ & 0.74 & 0.92 & 1.83 & 0.74 \\
\hline & 20.55 & 10.58 & 8.12 & 7.84 & 8.68 & $\mathrm{n} / \mathrm{a}$ & 8.36 & 9.51 & 14.35 & 4.33 \\
\hline & 0.15 & 0.05 & 0.14 & 0.06 & 0.08 & $\mathrm{n} / \mathrm{a}$ & 0.09 & 0.10 & 0.13 & 0.17 \\
\hline & 2.17 & -0.26 & 0.68 & -0.19 & -0.09 & $\mathrm{n} / \mathrm{a}$ & 0.10 & 0.52 & 0.90 & 0.19 \\
\hline \multirow[t]{4}{*}{ Hun } & 1.81 & 0.95 & 0.62 & $\mathrm{n} / \mathrm{a}$ & -0.46 & 1.31 & 2.19 & 0.50 & -0.72 & 0.59 \\
\hline & 12.75 & 11.66 & 10.55 & $\mathrm{n} / \mathrm{a}$ & 11.15 & 11.30 & 13.40 & 11.07 & 16.73 & 10.48 \\
\hline & 0.14 & 0.08 & 0.06 & $\mathrm{n} / \mathrm{a}$ & -0.04 & 0.12 & 0.16 & 0.05 & -0.04 & 0.06 \\
\hline & 0.89 & 0.19 & 0.12 & $\mathrm{n} / \mathrm{a}$ & -1.27 & 0.65 & 1.55 & 0.10 & -1.65 & 0.04 \\
\hline \multirow[t]{4}{*}{ India } & 0.66 & 1.29 & 0.97 & 1.07 & $\mathrm{n} / \mathrm{a}$ & 0.77 & 1.19 & 0.73 & 2.79 & 0.96 \\
\hline & 11.19 & 11.58 & 8.37 & 11.52 & $\mathrm{n} / \mathrm{a}$ & 7.58 & 12.43 & 13.17 & 16.41 & 11.21 \\
\hline & 0.06 & 0.11 & 0.12 & 0.09 & $\mathrm{n} / \mathrm{a}$ & 0.10 & 0.10 & 0.06 & 0.17 & 0.09 \\
\hline & -0.27 & 0.54 & 0.47 & 0.42 & $\mathrm{n} / \mathrm{a}$ & 0.10 & 0.56 & 0.33 & 1.85 & 0.41 \\
\hline \multirow[t]{4}{*}{ Israel } & 1.44 & 1.27 & 1.37 & 1.23 & 0.66 & 1.08 & 0.78 & 0.72 & 0.36 & 1.43 \\
\hline & 9.48 & 9.98 & 10.56 & 8.22 & 8.71 & 7.59 & 8.03 & 8.10 & 10.81 & 10.56 \\
\hline & 0.15 & 0.13 & 0.13 & 0.15 & 0.08 & 0.14 & 0.10 & 0.09 & 0.03 & 0.14 \\
\hline & 0.52 & 0.51 & 0.88 & 0.59 & -0.15 & 0.42 & 0.15 & 0.32 & -0.57 & 0.88 \\
\hline
\end{tabular}


Table 4 (Continued)

\begin{tabular}{|c|c|c|c|c|c|c|c|c|c|c|}
\hline Country & OilGas & BasMats & ConsGds & ConsSvs & Ind. & $\mathrm{HC}$ & Financ. & Telec. & Tech. & Utilit. \\
\hline \multirow[t]{4}{*}{ Mal } & 0.77 & 0.22 & 0.64 & 0.49 & 0.29 & 3.47 & 0.89 & 0.60 & 1.64 & 0.34 \\
\hline & 8.10 & 10.93 & 9.88 & 8.69 & 8.47 & 9.62 & 11.09 & 9.32 & 16.53 & 8.41 \\
\hline & 0.09 & 0.02 & 0.06 & 0.06 & 0.03 & 0.36 & 0.08 & 0.06 & 0.10 & 0.04 \\
\hline & -0.16 & -0.54 & 0.14 & -0.15 & -0.51 & 2.81 & 0.26 & 0.20 & 0.71 & -0.21 \\
\hline \multirow[t]{4}{*}{ Mex } & $\mathrm{n} / \mathrm{a}$ & 1.87 & -0.11 & 0.73 & 0.49 & 2.39 & 1.27 & $\mathrm{n} / \mathrm{a}$ & $\mathrm{n} / \mathrm{a}$ & 1.42 \\
\hline & $\mathrm{n} / \mathrm{a}$ & 12.14 & 12.66 & 9.09 & 11.92 & 12.19 & 11.19 & $\mathrm{n} / \mathrm{a}$ & $\mathrm{n} / \mathrm{a}$ & 9.42 \\
\hline & $\mathrm{n} / \mathrm{a}$ & 0.15 & -0.01 & 0.08 & 0.04 & 0.20 & 0.11 & $\mathrm{n} / \mathrm{a}$ & $\mathrm{n} / \mathrm{a}$ & 0.15 \\
\hline & $\mathrm{n} / \mathrm{a}$ & 1.11 & -0.61 & 0.09 & -0.32 & 1.73 & 0.64 & $\mathrm{n} / \mathrm{a}$ & $\mathrm{n} / \mathrm{a}$ & 0.86 \\
\hline \multirow[t]{4}{*}{ Pak } & 1.23 & 0.74 & 1.22 & 0.43 & 1.66 & 0.61 & 1.07 & 0.11 & $\mathrm{n} / \mathrm{a}$ & 0.57 \\
\hline & 12.38 & 9.90 & 9.97 & 16.44 & 30.18 & 9.75 & 11.72 & 12.70 & $\mathrm{n} / \mathrm{a}$ & 12.50 \\
\hline & 0.10 & 0.07 & 0.12 & 0.03 & 0.05 & 0.06 & 0.09 & 0.01 & $\mathrm{n} / \mathrm{a}$ & 0.05 \\
\hline & 0.30 & -0.02 & 0.72 & -0.21 & 0.85 & -0.05 & 0.44 & -0.29 & $\mathrm{n} / \mathrm{a}$ & 0.01 \\
\hline \multirow[t]{4}{*}{ Peru } & 1.23 & 1.09 & 0.55 & 4.01 & 2.28 & $\mathrm{n} / \mathrm{a}$ & 1.47 & 1.60 & $\mathrm{n} / \mathrm{a}$ & 0.73 \\
\hline & 17.56 & 7.96 & 5.99 & 25.09 & 21.51 & $\mathrm{n} / \mathrm{a}$ & 6.69 & 16.72 & $\mathrm{n} / \mathrm{a}$ & 6.54 \\
\hline & 0.07 & 0.14 & 0.09 & 0.16 & 0.11 & $\mathrm{n} / \mathrm{a}$ & 0.22 & 0.10 & $\mathrm{n} / \mathrm{a}$ & 0.11 \\
\hline & 0.31 & 0.33 & 0.05 & 3.37 & 1.47 & $\mathrm{n} / \mathrm{a}$ & 0.83 & 1.20 & $\mathrm{n} / \mathrm{a}$ & 0.17 \\
\hline \multirow[t]{4}{*}{ Phil } & 0.54 & 0.60 & 0.44 & 0.19 & 0.84 & $\mathrm{n} / \mathrm{a}$ & 0.43 & 0.55 & $\mathrm{n} / \mathrm{a}$ & 0.62 \\
\hline & 14.66 & 17.36 & 8.19 & 11.56 & 12.09 & $\mathrm{n} / \mathrm{a}$ & 10.23 & 8.99 & $\mathrm{n} / \mathrm{a}$ & 11.47 \\
\hline & 0.04 & 0.03 & 0.05 & 0.02 & 0.07 & $\mathrm{n} / \mathrm{a}$ & 0.04 & 0.06 & $\mathrm{n} / \mathrm{a}$ & 0.05 \\
\hline & -0.38 & -0.16 & -0.05 & -0.45 & 0.03 & $\mathrm{n} / \mathrm{a}$ & -0.20 & 0.15 & $\mathrm{n} / \mathrm{a}$ & 0.07 \\
\hline \multirow[t]{4}{*}{ Pol } & 1.11 & 1.79 & 0.80 & 1.40 & 0.30 & $\mathrm{n} / \mathrm{a}$ & 1.20 & 0.64 & 0.57 & 1.30 \\
\hline & 10.47 & 12.36 & 8.54 & 11.73 & 10.83 & $\mathrm{n} / \mathrm{a}$ & 10.90 & 10.70 & 12.66 & 12.99 \\
\hline & 0.11 & 0.14 & 0.09 & 0.12 & 0.03 & $\mathrm{n} / \mathrm{a}$ & 0.11 & 0.06 & 0.05 & 0.10 \\
\hline & 0.19 & 1.03 & 0.31 & 0.76 & -0.51 & $\mathrm{n} / \mathrm{a}$ & 0.56 & 0.24 & -0.36 & 0.75 \\
\hline \multirow[t]{4}{*}{ Russia } & 1.99 & 2.45 & 2.32 & 3.91 & 2.83 & 1.22 & 3.50 & 1.72 & $\mathrm{n} / \mathrm{a}$ & 1.82 \\
\hline & 14.48 & 13.34 & 12.26 & 15.77 & 19.60 & 17.17 & 21.51 & 16.10 & $\mathrm{n} / \mathrm{a}$ & 18.85 \\
\hline & 0.14 & 0.18 & 0.19 & 0.25 & 0.14 & 0.07 & 0.16 & 0.11 & $\mathrm{n} / \mathrm{a}$ & 0.10 \\
\hline & 1.07 & 1.69 & 1.82 & 3.27 & 2.02 & 0.56 & 2.87 & 1.32 & $\mathrm{n} / \mathrm{a}$ & 1.27 \\
\hline \multirow[t]{4}{*}{ Sing } & 1.05 & 1.21 & 1.16 & 0.63 & 0.64 & 0.67 & 0.68 & 0.43 & 0.14 & 3.13 \\
\hline & 12.13 & 14.33 & 11.19 & 7.11 & 7.42 & 8.03 & 8.91 & 7.07 & 14.58 & 15.80 \\
\hline & 0.09 & 0.08 & 0.10 & 0.09 & 0.09 & 0.08 & 0.08 & 0.06 & 0.01 & 0.20 \\
\hline & 0.13 & 0.45 & 0.66 & -0.01 & -0.17 & 0.01 & 0.04 & 0.03 & -0.79 & 2.58 \\
\hline \multirow[t]{4}{*}{ SA } & 1.26 & 0.98 & 1.45 & 1.03 & 0.88 & 1.04 & 0.95 & 2.12 & $\mathrm{n} / \mathrm{a}$ & $\mathrm{n} / \mathrm{a}$ \\
\hline & 10.26 & 12.40 & 11.11 & 10.17 & 9.83 & 9.32 & 9.47 & 13.89 & $\mathrm{n} / \mathrm{a}$ & $\mathrm{n} / \mathrm{a}$ \\
\hline & 0.12 & 0.08 & 0.13 & 0.10 & 0.09 & 0.11 & 0.10 & 0.15 & $\mathrm{n} / \mathrm{a}$ & $\mathrm{n} / \mathrm{a}$ \\
\hline & 0.34 & 0.23 & 0.95 & 0.39 & 0.07 & 0.38 & 0.31 & 1.72 & $\mathrm{n} / \mathrm{a}$ & $\mathrm{n} / \mathrm{a}$ \\
\hline \multirow[t]{4}{*}{ Sri Lanka } & 1.78 & $\mathrm{n} / \mathrm{a}$ & 0.84 & 0.48 & 0.89 & $\mathrm{n} / \mathrm{a}$ & 0.59 & 0.45 & $\mathrm{n} / \mathrm{a}$ & -9.26 \\
\hline & 9.59 & $\mathrm{n} / \mathrm{a}$ & 8.94 & 9.72 & 9.62 & $\mathrm{n} / \mathrm{a}$ & 8.85 & 9.55 & $\mathrm{n} / \mathrm{a}$ & 6.98 \\
\hline & 0.19 & $\mathrm{n} / \mathrm{a}$ & 0.09 & 0.05 & 0.09 & $\mathrm{n} / \mathrm{a}$ & 0.07 & 0.05 & $\mathrm{n} / \mathrm{a}$ & -1.33 \\
\hline & 0.86 & $\mathrm{n} / \mathrm{a}$ & 0.34 & -0.16 & 0.08 & $\mathrm{n} / \mathrm{a}$ & -0.05 & 0.05 & $\mathrm{n} / \mathrm{a}$ & -9.81 \\
\hline
\end{tabular}


Table 4 (Continued)

\begin{tabular}{ccccccccccc}
\hline Country & OilGas & BasMats & ConsGds & ConsSvs & Ind. & HC & Financ. & Telec. & Tech. & Utilit. \\
\hline Taiwan & 1.20 & 0.84 & 0.74 & 0.03 & 0.84 & $\mathrm{n} / \mathrm{a}$ & 0.01 & 0.42 & 1.20 & $\mathrm{n} / \mathrm{a}$ \\
& 6.94 & 7.91 & 9.39 & 8.37 & 10.89 & $\mathrm{n} / \mathrm{a}$ & 10.20 & 6.42 & 11.93 & $\mathrm{n} / \mathrm{a}$ \\
& 0.17 & 0.11 & 0.08 & 0.00 & 0.08 & $\mathrm{n} / \mathrm{a}$ & 0.00 & 0.07 & 0.10 & $\mathrm{n} / \mathrm{a}$ \\
\multirow{4}{*}{ Thai } & 0.27 & 0.08 & 0.25 & -0.61 & 0.04 & $\mathrm{n} / \mathrm{a}$ & -0.63 & 0.02 & 0.27 & $\mathrm{n} / \mathrm{a}$ \\
& 1.25 & 0.98 & 1.02 & 0.75 & 1.47 & 0.82 & 0.38 & 0.66 & 1.26 & 0.89 \\
& 11.04 & 16.20 & 13.23 & 9.41 & 14.21 & 8.89 & 14.34 & 12.73 & 15.88 & 10.26 \\
& 0.11 & 0.06 & 0.08 & 0.08 & 0.10 & 0.09 & 0.03 & 0.05 & 0.08 & 0.09 \\
Turkey & 0.32 & 0.22 & 0.52 & 0.11 & 0.67 & 0.16 & -0.26 & 0.26 & 0.33 & 0.34 \\
& 1.92 & 2.32 & 1.83 & 1.96 & 2.08 & 3.07 & 2.32 & 2.05 & 3.36 & 2.64 \\
& 17.21 & 16.75 & 15.58 & 18.81 & 17.33 & 16.69 & 16.96 & 19.42 & 21.29 & 19.11 \\
& 0.11 & 0.14 & 0.12 & 0.10 & 0.12 & 0.18 & 0.14 & 0.11 & 0.16 & 0.14 \\
Emerg & 0.99 & 1.56 & 1.33 & 1.32 & 1.27 & 2.41 & 1.68 & 1.65 & 2.43 & 2.08 \\
& $\mathbf{1 . 3 5}$ & $\mathbf{1 . 1 8}$ & $\mathbf{1 . 0 2}$ & $\mathbf{1 . 2 0}$ & $\mathbf{1 . 0 3}$ & $\mathbf{1 . 6 7}$ & $\mathbf{1 . 1 3}$ & $\mathbf{0 . 8 7}$ & $\mathbf{1 . 3 8}$ & $\mathbf{0 . 5 9}$ \\
& 11.77 & 11.58 & 10.12 & 11.32 & 12.33 & 11.13 & 10.79 & 10.98 & 14.01 & 10.54 \\
& 0.15 & 0.14 & 0.14 & 0.14 & 0.12 & 0.15 & 0.14 & 0.12 & 0.10 & 0.07 \\
& 0.43 & 0.42 & 0.52 & 0.56 & 0.22 & 1.00 & 0.50 & 0.47 & 0.45 & 0.04 \\
\hline
\end{tabular}

Source: Based on Donadelli and Lucchetta (2012).

(utilities) to a maximum of $1.00 \%$ (healthcare). It turns out that most of the extra performance has been driven by the healthcare sector over the period January 1995-June 2012.

\subsection{International Stock Market Co-Movements}

The dynamics of the co-movement between returns is very important in finance. A key ingredient in the mean-variance portfolio optimization world is represented by the variance-covariance matrix of stock returns. In particular, the analysis of the correlation coefficients between international excess returns as well as the study of the co-movement between international returns and leading economic indicators are crucial for portfolio stability and diversification strategies. This subsection examines the unconditional correlation between national stock market excess returns (Figure 1) as well as between emerging stock market sector excess returns and the MSCI World excess return (Figure 2), and the conditional correlation between an indicator of economic policy uncertainty in the US and a set of regional stock market sector excess returns (Figure 3). The unconditional correlation coefficients are estimated using a rolling window of 60 months over the period January 1988 (or later)-December 2011. The dynamic conditional correlation is computed in a DCC-GARCH context. All co-movement measures suggest that cross-country and cross-industry diversification benefits are smaller than in the past (i.e., emerging and advanced stock market indexes tend to move together). 

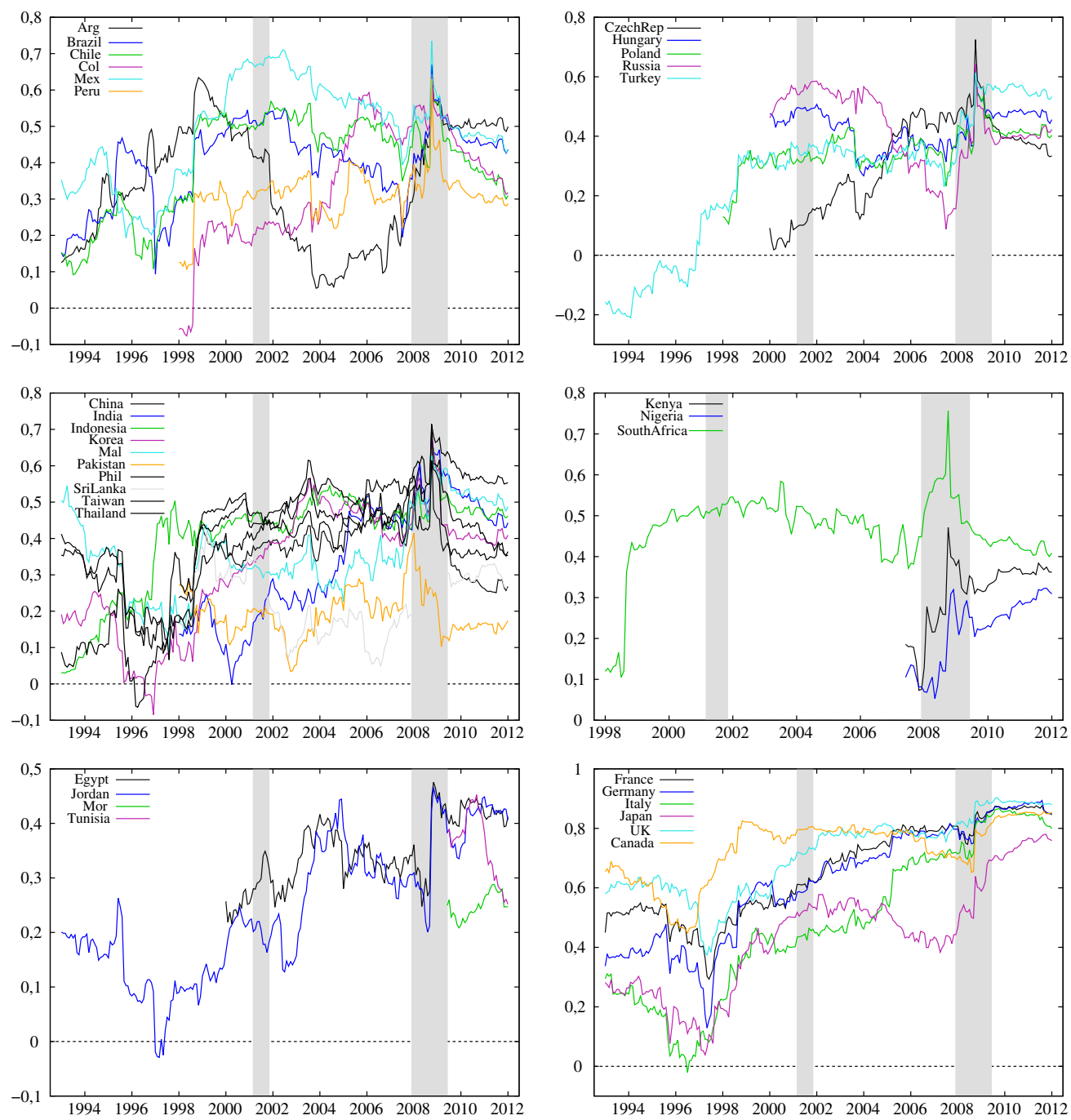

Figure 1 Dynamic unconditional correlation (international stock market excess returns vs US stock market excess return). Sample: January 1988 (or later)-December 2011. Note: The shaded vertical bars in all graphs denote NBER-dated recessions.

Source: Based on Donadelli (2013a).

\subsubsection{Emerging vs Advanced Stock Market Excess Returns}

Figure 1 reports the dynamics of the correlation coefficients between 28 emerging and 6 advanced stock market excess returns, and the excess returns of the US stock market. Figure 2 reports the dynamic unconditional correlation between the excess returns of 10 emerging stock market sector excess returns and the excess returns of the MSCI World. Dynamic unconditional correlations are obtained using a rolling window of 60 months.

Four empirical findings are worth noting: (i) correlation coefficients are increasing both across emerging and advanced stock markets; (ii) the correlation between the 


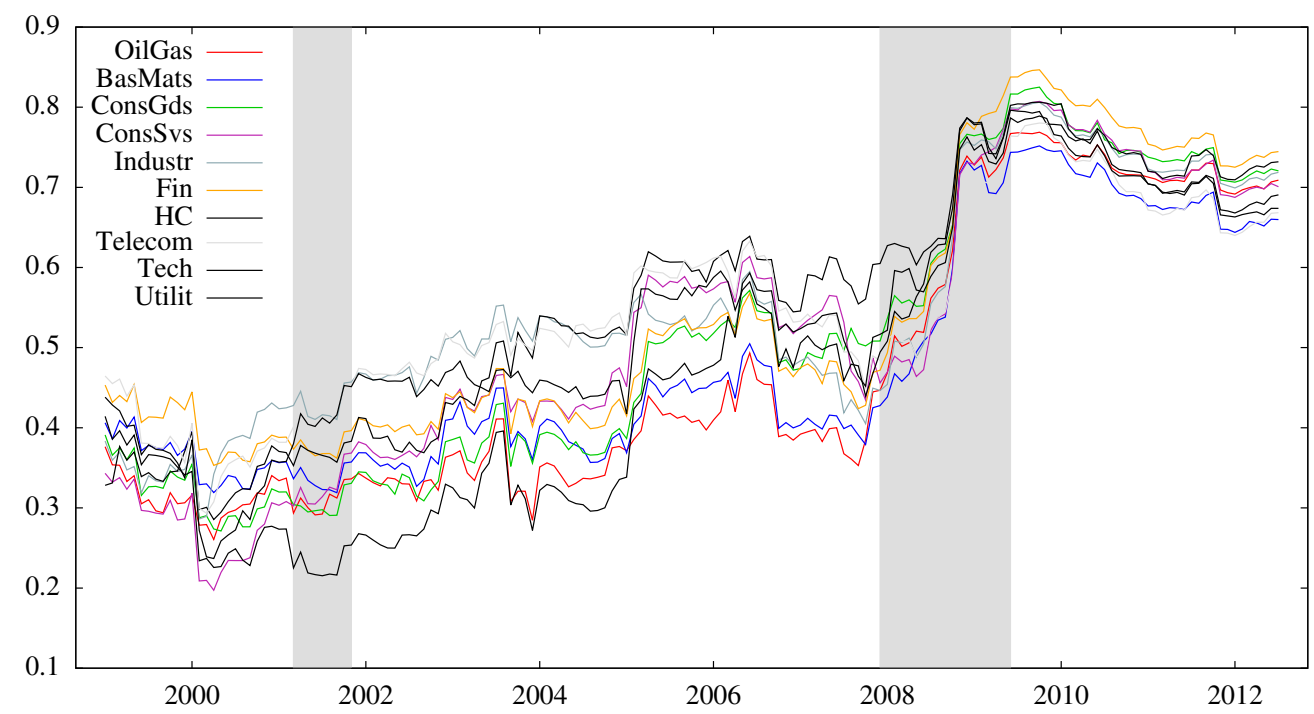

Figure 2 Dynamic unconditional correlation (emerging stock market sector excess returns vs MSCl World excess return). Sample: January 1994-June 2012. Note: The shaded vertical bars in all graphs denote NBER-dated recessions.

Source: Based on Donadelli (2013b).

advanced stock market excess returns and the excess return of the US stock market is (on average) higher than the correlation between the emerging stock market excess returns and the excess return of the US stock market; (iii) differently from the 9/11 recession, during the 2007-2009 US subprime crisis financial contagion took place in all stock markets; and (iv) the correlation between emerging stock market sector excess returns and the world portfolio excess return is increasing over time.

While standard international asset pricing models predict that financial liberalization may reduce the cost of capital, an increasing integration process across financial and goods markets tends to reduce international portfolio diversification benefits, thus, forcing investors to look for alternative forms of investment.

\subsubsection{Excess Returns vs Macroeconomic Policy Uncertainty}

In the spirit of Antonakakis et al. (2012), this subsection examines the extent of timevarying co-movements between stock returns and a newly introduced measure of US economic policy uncertainty. Dynamic correlations are computed in a DCC-GARCH framework. ${ }^{9}$ In contrast to Antonakakis et al. (2012), who focus on the US stock market, this subsection focuses also on emerging stock markets. In particular, we rely on four regions in a sector-by-sector context. Figure 3 reports the dynamic conditional correlation between the US economic policy uncertainty index and the excess returns of 10 stock sector indexes in three emerging regions and in the US. The US economic

\footnotetext{
${ }^{9}$ For a formal discussion on the DCC-GARCH procedure, see Engle (2002).
} 

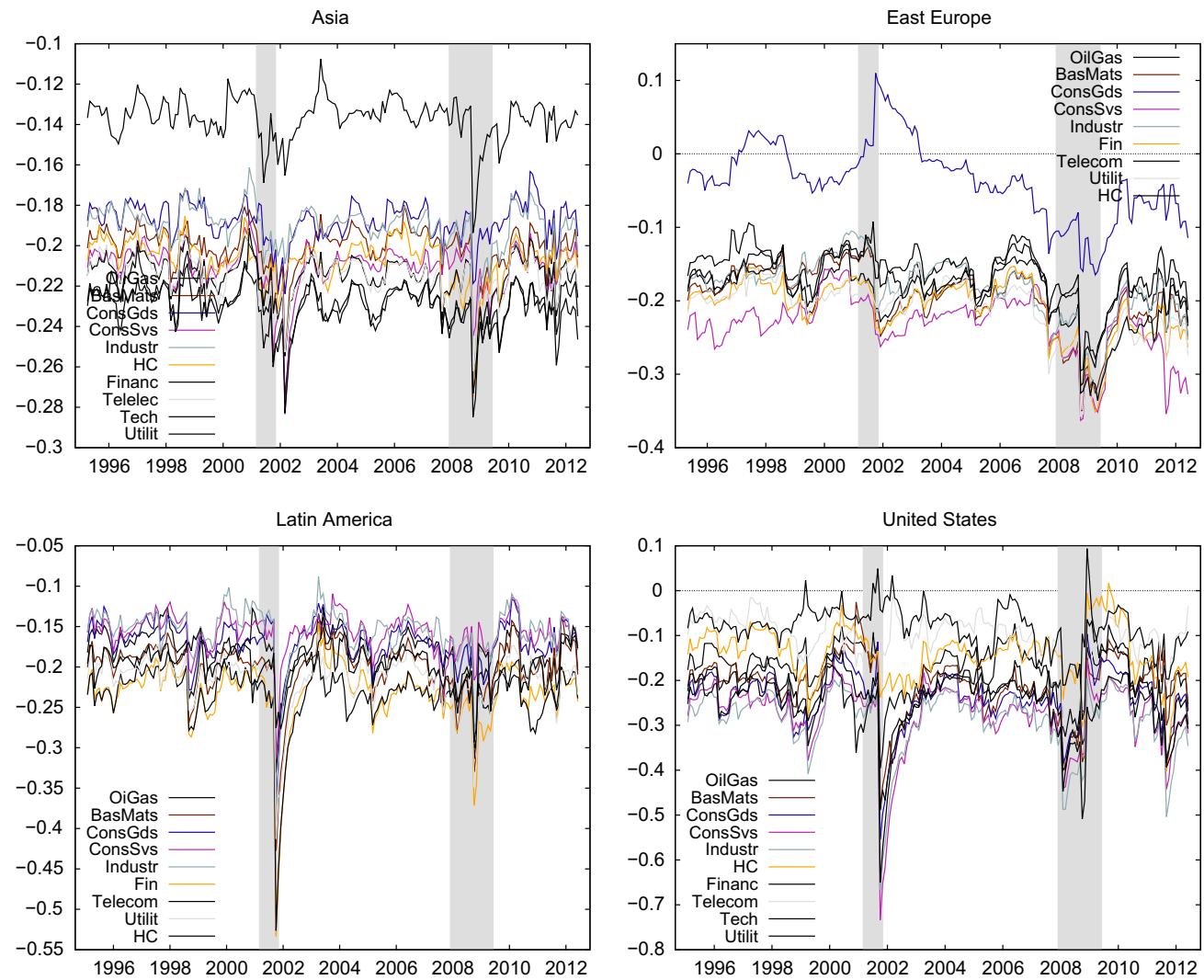

Figure 3 Dynamic conditional correlation (US economic policy uncertainty vs stock market sector excess returns). Sample: January 1995 (or later)-June 2012. Note: Shading denotes US recessions as defined by NBER.

Source: Based on Donadelli and Persha (2014).

policy uncertainty measure is from Baker et al. (2012). Regional stock sector indexes have been created as weighted average of country stock market sector indexes. Both in the US and in the emerging world, the time-varying correlation between excess returns and uncertainty is consistently negative over time (i.e., stock excess returns decrease with increasing macro uncertainty). An exception is given by the consumer goods sector in Eastern Europe. Results represented in Figures 2 and 3 confirm that emerging and US stock markets tend to follow similar patterns (i.e., a reduction in international portfolio diversification benefits).

\section{A TIME-VARYING ANALYSIS}

Early works observe that emerging stock markets tend to display high volatility, low correlations with developed markets and within emerging markets, and high long-horizon returns. Other early studies examining international stock return predictability find that 
emerging stock market returns are mainly influenced by local risk factors rather than by global risk sources. Most of these studies are developed in a static context, employ a "contaminated dataset," and focus only on stock market country indexes. This section employs a newer dataset to study the performance and the financial integration level of international stock markets as well as the impact of the global integration process on international stock market prices in a dynamic context. The analysis is conducted in a pure rolling-window world, and relies on the following performance and integration measures: (i) Sharpe ratios; (ii) the $\bar{R}^{2}$ of a multi-(artificial) factor regression; (iii) market openness (i.e., trade-to-GDP ratio); and (iv) unexpected excess returns (i.e., Jensen's alpha).

\subsection{On the Excess Returns}

Emerging stock markets tend to deliver generous average excess returns (Grootveld and Salomons, 2003; Harvey, 1995a,b; Donadelli, 2013a; Donadelli and Prosperi, 2012). It is popularly believed that such behavior is mainly driven by the fact that emerging markets are perceived to be more risky than advanced markets. Barry et al. (1997) and Claessens et al. (1995), among many others, observe that emerging markets' investments provide risk/return benefits. Most of these studies argue that investors are compensated for bearing the risks in terms of higher average returns and a low correlation with developed markets and among other emerging markets. Grootveld and Salomons (2003) examine differences and similarities of the ERP in emerging and developed markets over different time-horizons. They find that the ERP in emerging markets is significantly higher than in developed markets. Donadelli and Lucchetta (2012) and Donadelli (2013b), in a sector-by-sector context, confirm that emerging stock markets tend to deliver higher average excess returns. Via a pure rolling-window analysis, they also show that the first and second moment of the international stock market excess returns are heavily time-varying. Bekaert et al. (1998) observe that the structure of the return distribution of emerging markets is potentially unstable. Grootveld and Salomons (2003) also show that ERP tends to be less stable through time in emerging markets. Using MSCI TRI for 25 emerging national stock markets they argue that much of the instability of emerging ERP is generated by the emerging market crises of the 1990s, the financial market liberalizations, and the higher exposure of emerging stock markets to global business cycles. ${ }^{10}$ Figure 4 shows the dynamics of the Sharpe ratio for seven equal- (left panel), GDP- (middle panel), and trade- (right panel) weighted regional indexes (i.e. macro portfolios). Figure 5 shows the dynamics of the Sharpe ratio for 10 emerging (left panel) and US (right panel) stock market sector indexes. Emerging sector indexes are equally weighted averages of countries' sector indexes. Both figures confirm and update most of the existing empirical findings.

The updated empirical results can be summarized as follows: (i) emerging stock markets have provided a higher risk-return performance than advanced stock markets over

10 Bekaert et al. (1998) develop a similar discussion. 

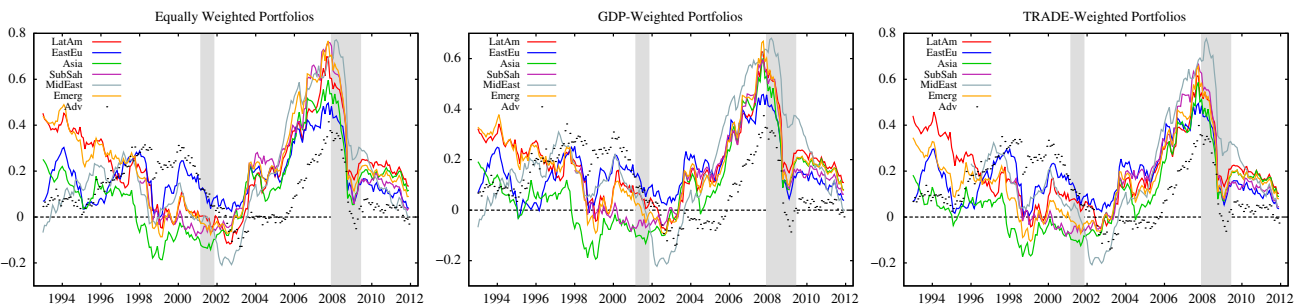

Figure 4 This figure reports the dynamics of the Sharpe ratio for seven macro stock markets. Estimates are computed on rolling basis using a window of 60 months. Sample: January 1988 (or later)-December 2011. Note: The shaded vertical bars denote NBER-dated recessions.

Source: Based on Donadelli and Prosperi (2012).
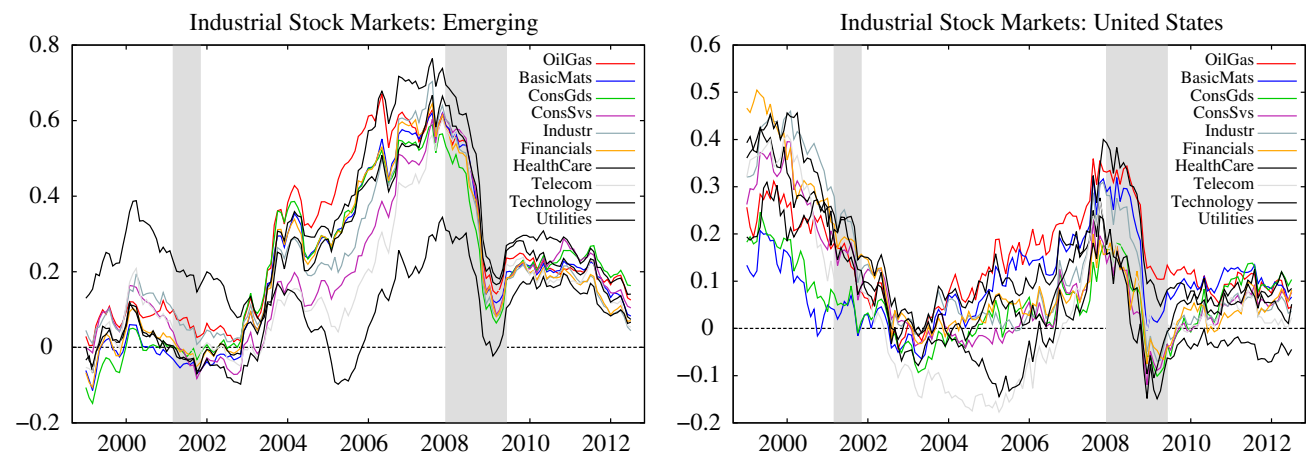

Figure 5 This figure report the dynamics of the Sharpe ratio for 10 US and emerging industrial stock markets. Estimates are computed on rolling basis using a window of 60 months. Sample: January 1994 (or later)-June 2012. Note: The shaded vertical bars denote NBER-dated recessions.

Source: Based on Donadelli (2013b).

the last 10 years (see dotted black line of Figure 4); (ii) emerging market performances have been heavily influenced by domestic shocks, such as the Tequila crisis in Mexico and the Asian financial crisis (see the left-hand side of each plot in Figures 4 and 5); (iii) international stock market indexes are increasing during the no-crises period (i.e., between the 9/11 terrorist attacks and the 2007 subprime crisis); and (iv) the joint collapse of international stock market country and sector indexes during the last crisis provides evidence for the existence of contagion. ${ }^{11}$

\subsection{On the Global Integration}

The effects of equity market liberalizations on international stock market prices and the dynamics of correlations between advanced and emerging stock markets have been largely examined. It is largely accepted that liberalizations and increasing correlations have made emerging stock markets increasingly integrated. However, the debate on whether or

11 For a detailed discussion on the contagion effects, see Corsetti et al. (2005). 
not emerging market are fully integrate is still open. For example, Bekaert et al. (2003) observe that it is important to distinguish between the concepts of liberalization and integration. Specifically, a country might pass a law that drops all barriers to foreign participation in local capital markets but still be partially segmented. They argue that the market might have been integrated before the regulatory liberalization. Therefore, it is crucial to distinguish between the de jure and the de facto integration.

While several studies have examined the effects of the de jure integration, a limited number of works have been devoted to study the effects of the de facto integration on international stock market prices. This subsection studies the dynamics of the real and financial integration processes as well as its impact on emerging and advanced stock market excess returns. Real integration, both at local and global level, is captured by the degree of market openness (i.e., trade-to-GDP ratio), namely integration index. ${ }^{12}$ The global and regional integration indexes (GII and RII) are defined as follows:

$$
\begin{aligned}
\mathrm{GII} & =\frac{\sum_{i, t}^{I} \operatorname{Trade}_{i, t}}{\sum_{j, t_{4}} \operatorname{GDP}_{j, t_{4}}} \\
\mathrm{RII} & =\frac{\sum_{n, t}^{N} \operatorname{Trade}_{n, t}}{\text { WORLD GDP }_{t_{12}}},
\end{aligned}
$$

where $t, t_{4}$, and $t_{12}$ denote monthly, quarterly, and annually frequency, respectively. The subscripts $i$ and $j$ represent the country and the OECD member, respectively, and $I$ denotes the total number of countries. ${ }^{13}$ The subscript $n$ denotes a country in each region and $N$ is the total number of countries in a region, and WORLD GDP $t_{12}$ is the annual WORLD GDP-measured in US dollars — of the IMF.

Figure 6 reports the rate of change and the cumulative rate of change of the real integration measure. The dynamics of the emerging integration indexes are reported in Figure 7. All figures suggest that the degree of market openness, both at the global and regional level, has largely increased during the last 10 years. The integration growth across emerging economies in the period 2002-2009 is particularly steep and noteworthy. Not surprisingly, market openness in Asia is higher than in the other emerging regions, and seems to drive real integration in the emerging world.

In the spirit of Pukthuanthong and Roll (2009), de facto financial integration is measured by using the $\bar{R}^{2}$ of a multi-(artificial) factor linear model where the risk sources are

12 A similar measure has been used by de Jong and de Roon (2005), Liao and Santacreu (2012), and Santacreu (2012), among others.

13 Global trade is represented by the sum of the trade of all regions (i.e., sum imports and exports of goods of 28 emerging and 7 advanced countries). Global GDP is given by the sum of all OECD members GDPs. The OECD Total covers the following 34 countries: Australia, Austria, Belgium, Canada, Chile, Czech Republic, Denmark, Estonia, Finland, France, Germany, Greece, Hungary, Iceland, Ireland, Israel, Italy, Japan, Korea, Luxembourg, Mexico, Netherlands, New Zealand, Norway, Poland, Portugal, Slovak Republic, Slovenia, Spain, Sweden, Switzerland,Turkey, United Kingdom, and United States. Since OECD data can be observed only on quarterly basis, the denominator of the index is assumed to be fixed within a quarter. All variables are denominated in US\$. 

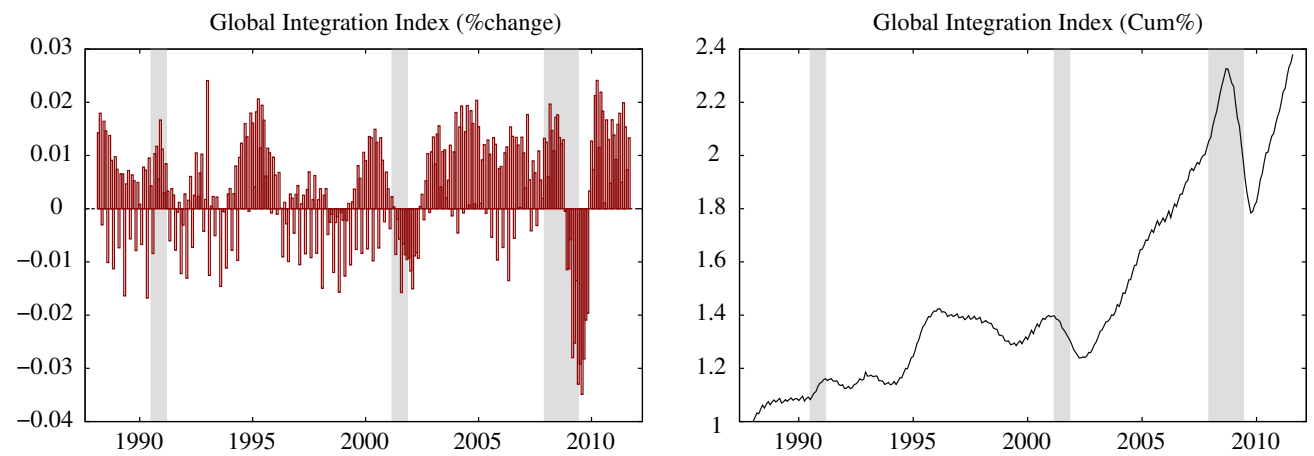

Figure 6 This figure reports the rate of change (\%) and the cumulative rate of change (\%) of the GII (i.e., global trade-to-GDP ratio). Sample: January 1988-December 2011. The Gll is computed as in Eq. (4). Note: The shaded vertical bars denote NBER-dated recessions.

Source: Based on Donadelli (2013a).
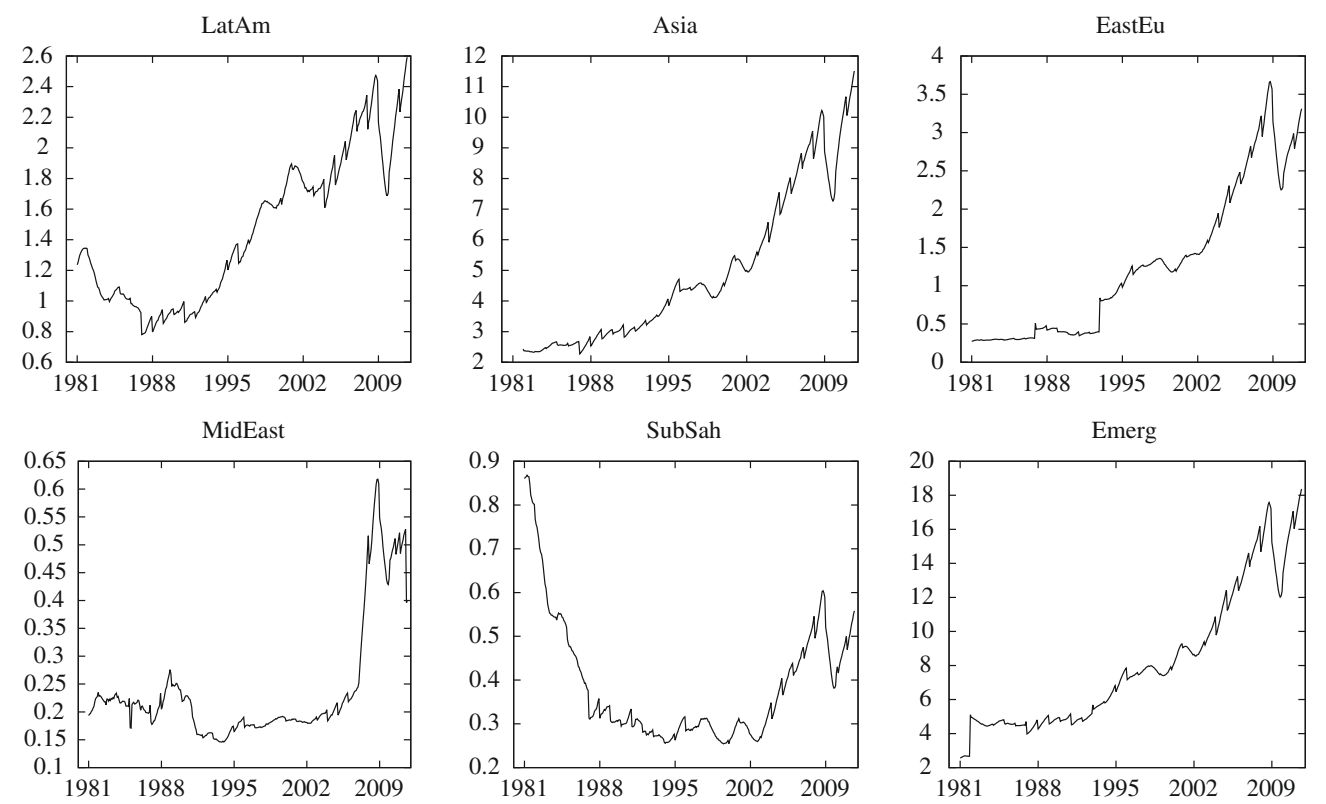

Figure 7 This figure reports the dynamics of the RII (i.e., regional trade-to-GDP ratio) for the following emerging regions: Latin America, Asia, Eastern Europe, Middle East, Sub-Saharan, and Emerging. The RII is computed as in Eq. (5) and expressed in percentage points (vertical axis). Sample: January 1981December 2011.

Source: Global Financial Data and IMF. 
represented by the first 10 principal components extracted from a large set of variables. ${ }^{14}$ In Eq. (6), global risk factors (i.e., principal components) are extracted from a dataset composed by 19 stock market country excess returns. In Eq. (7), the global risk factors are extracted from a larger set of variables. The set is composed by 146 variables (i.e., country-by-country and sector-by-sector stock market excess returns): ${ }^{15}$

$$
\begin{aligned}
& \operatorname{ExRet}_{n, t}^{w}=\alpha_{n}^{w}+\sum_{c=1}^{10} \psi_{c}^{w} G R F_{c, t}^{w}+\epsilon_{n, t}^{w}, \\
& \operatorname{ExRet}_{i, t}^{w}=\alpha_{i}^{w}+\sum_{c=1}^{10} \psi_{c}^{w} G R F_{c, t}^{w}+\epsilon_{i, t}^{w} .
\end{aligned}
$$

The $\bar{R}^{2} s$, obtained by estimating Eqs. (6) and (7) in a rolling-window framework, capture the degree of financial openness, both at the country and sector level, across international stock markets. Figure 8 reports the dynamics of the average $\bar{R}^{2}$ for the international stock markets. ${ }^{16}$ Figure 9 reports the dynamics of the $\bar{R}^{2}$ in a sector-by-sector context.
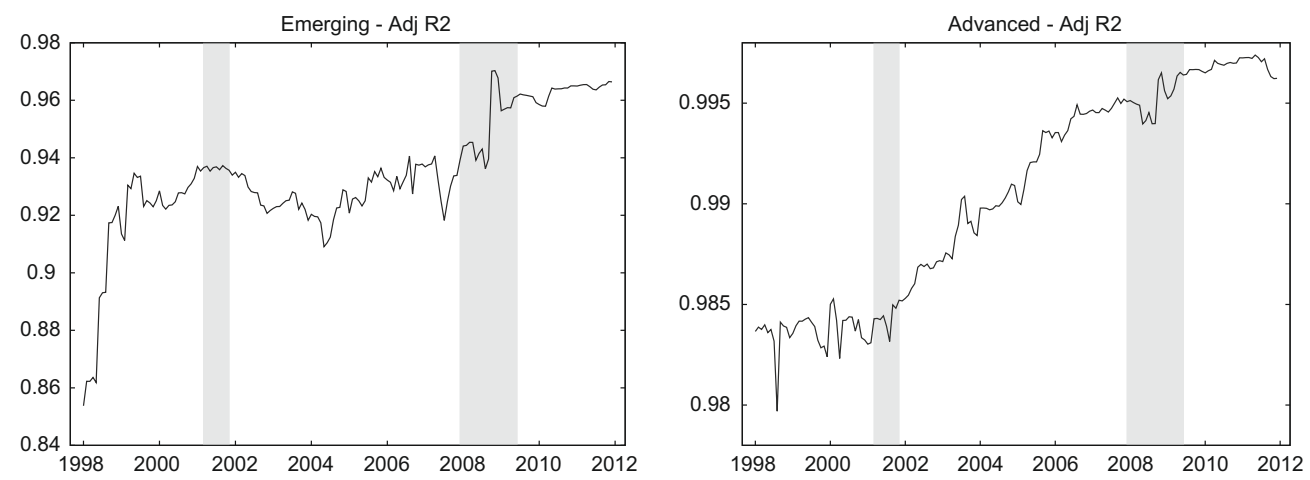

Figure 8 This figure reports the dynamics of the average $\bar{R}^{2}$. Advanced average $\bar{R}^{2}$ is averaged over the G7 economies. Emerging average $\bar{R}^{2}$ is averaged over 28 emerging economies. Estimates are computed on rolling basis using a window of 60 months. Sample: January 1998-December 2011. Note: The shaded vertical bars denote NBER-dated recessions.

Source: Based on Donadelli $(2013 a, b)$.

${ }^{14}$ As suggested by Pukthuanthong and Roll (2009), the first 10 principal components should explain 90\% of the variation across data.

15 Details on the principal component analysis are given in Donadelli (2013a,b).

16 The financial integration measure is computed, in each window, for 7 advanced economies and for 28 emerging economies. The average $\bar{R}^{2}$ :

$$
\bar{R}_{w, a v g}^{2}=\frac{1}{N} \sum_{n=1}^{N} \bar{R}_{w, n}^{2}
$$

where $n$ denotes the country, $N$ is the total number of countries, and $w$ is the window in which the $\bar{R}^{2}$ is estimated. 

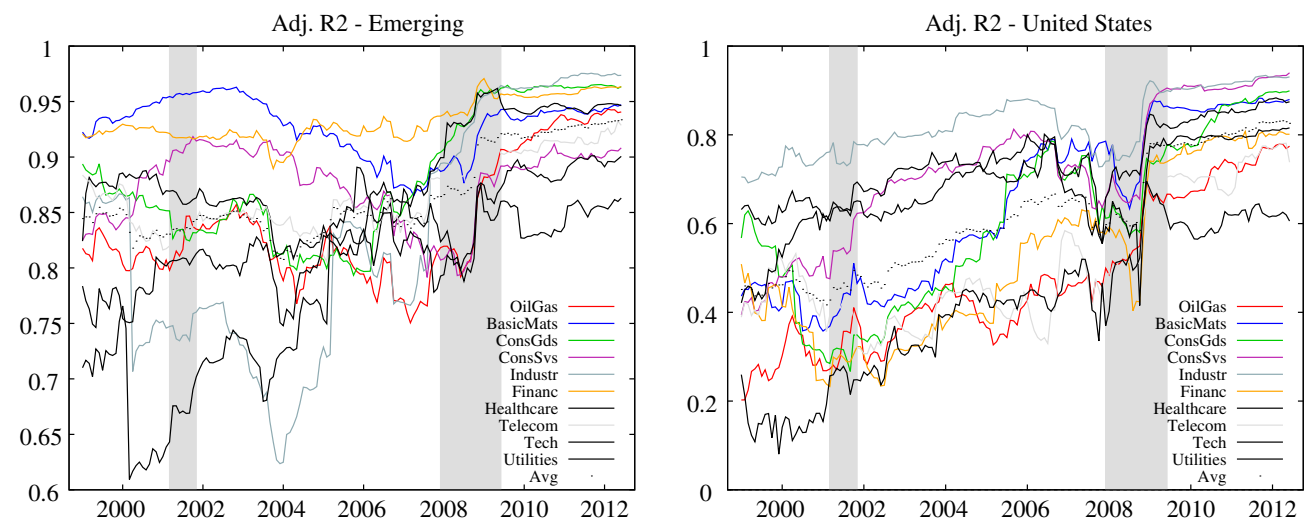

Figure 9 This figure reports the dynamics of the $\bar{R}^{2}$ : A sector-by-sector approach. Emerging stock market sector indexes are computed as weighted average of emerging countries' stock market sector indexes. Estimates are computed on rolling basis using a window of 60 months. Sample: January 1994 (or later)-June 2012. Note: The shaded vertical bars denote NBER-dated recessions.

Source: Based on Donadelli (2013b).

The joint analysis of Figures 6-9 suggests that: (i) the real and financial integration processes follow a similar path; (ii) the increasing path of the emerging stock market country and sector indexes during the last two NBER-dated recessions is followed by an increasing financial and real integration process (i.e., emerging excess returns increase as financial openness and the degree of market openness increase); (iii) the financial integration process across emerging economies has been influenced by the emerging crises of the late 1990s and early 2000s; and (iv) while emerging and advanced markets are both increasingly integrated, the integration process across emerging economies is unstable and seems to be influenced by local shocks (see left-panel of Figure 9).

\subsection{On "Model's Validity"}

The debate on whether or not global factors are the most important source of variation in international stock market excess returns is still widely open. Early studies, based on the high level of segmentation of emerging financial markets, argue that local microeconomic and macroeconomic variables have more explanatory variables than global variables over stock returns. To explain variation in international stock market excess returns, and especially in emerging stock markets, a large part of the empirical finance literature employs multi-factor linear models. On the one hand, early studies assume that emerging markets are segmented. On the other hand, most recent works assume that markets are perfectly integrated. While in a fully integrated environment variation in international stock returns can be fully explained by global risk sources, in a segmented world only local risk sources matter. In addition, few works employ both local and global risk sources to model international stock returns (Bilson et al., 2001). Harvey (1995a) examines the sensitivity 
of emerging market returns over the period 1976 (or later)-1992. He provides estimates of the one-factor model (i.e., world CAPM), both at the country and sector level, and finds that the loading on the MSCI world market index portfolio is significantly different from zero in each of the industrial stock markets, but only in 7 (out of 20) emerging markets. He also finds that the intercept is rarely equal to zero across emerging markets (i.e., model's validity is not preserved). Similarly, in the spirit of Ferson and Harvey (1994) and Bilson et al. (2001), via a multi-factor linear asset pricing model, find that the loading on the MSCI world market index portfolio is significantly different from 0 in 10 (out of 20) emerging national stock markets over the period February 1985-December 1997. Harvey (1995b) explores reasons why the emerging equities have high expected returns. In an asset pricing theory framework, high expected returns should be associated with large exposures to risk factors. However, he finds that the exposures to the commonly used risk factors are low. Again, standard asset pricing models seem to be unable to explain the cross-section of expected returns. Harvey (1995b) argues that emerging markets are segmented from world capital markets. It turns out that emerging market returns tend to be mainly influenced by local information variables. One possible reason for this failure is that the exposure of emerging markets to risk sources is time-varying.

While many studies have focused on the sensitiveness of emerging stock returns to either local or global risk sources, and employ pre-2000 data, this research focuses also on model's validity (i.e., unexpected excess returns or Jensens' alpha) in an updated international finance environment. Given that emerging markets present a strong time-varying component and have become more integrated, more recent studies find that the sensitivity of emerging market returns to measure of global risk is stronger. In a country-bycountry framework, Donadelli and Prosperi (2012) test the validity of the world CAPM for 13 developed and 19 emerging national stock markets, and for 6 macro-area portfolios. They report estimates for two different time-horizons, January 1995-December 2010 and January 2000-December 2010. In contrast to existing empirical findings, they show that the beta of the world CAPM is statistically different from zero in all developed, emerging, and region markets. Given an increasing degree of co-movements between international stock markets, the result seems to be intuitive.

Estimates suggest also that model's validity across emerging markets is rarely preserved (i.e., emerging intercepts are statistically different from zero). In addition, emerging alphas are always larger than advanced alphas, suggesting that emerging stock markets tend to generate higher average unexpected excess returns, namely the alpha puzzle (Donadelli and Prosperi, 2012). Donadelli and Prosperi (2012) solve the puzzle by developing a two-country one-period model with quadratic costs. Accounting for time-variation in the risk exposures and the expected returns, in a two-factor conditional version of the CAPM, Donadelli and Prosperi (2012) also show that global liquidity affects both the market price of risk and emerging realized excess returns. As global liquidity proxies, they employ the VIX and the open interest on the US stock market. However, the conditional 

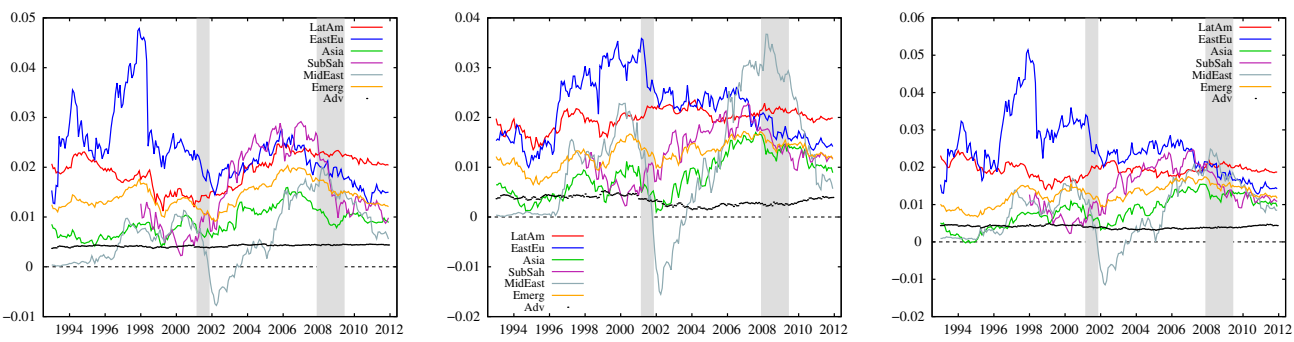

Figure 10 This figure reports the dynamics of the "PCA Alpha" for the equal- (left panel), GDP- (middle panel), and trade- (right panel) weighted portfolios. Estimations are performed on rolling basis using a window of 60 months. Sample: January 1988 (or later)-December 2011. Note: The shaded vertical bars denote NBER-dated recessions.

Source: Based on Donadelli (2013a).

version still delivers positive and statistically different from zero alphas. To explain variation across emerging and US industrial stock market returns, Donadelli (2013b) estimates four different linear-factor models using traded and non-traded global risk factors in a sectorby-sector context. Traded risk factors are commonly obtained from Fama \& French. Non-traded factors are represented by global macro variables (e.g. US industrial production growth rate, $10 Y$ Italian-German Bund Spread, the steepness of the US yield curve, VIX), and by the principal components extracted from a large set of variables. Results suggest that international stock market excess returns tend to be influenced by the same global risk sources. However, emerging markets contrast with the US market in at least one respect. In practice, emerging markets display are positive and statistically different from zero alphas. The result seems to be consistent across different factor models.

Figure 10 reports the dynamics of the intercept_obtained by estimating Eq. (6) in a rolling-window framework-for seven regional stock markets. Figure 11 reports the dynamics of the intercept-obtained by estimating Eq. (7) in a rolling-window framework - for 10 sectors in the emerging and US stock markets. Not surprisingly, emerging alphas present a strong time-varying component and are significantly larger than advanced stock market alphas. The result confirms the unstable industrial structure of emerging stock markets as well as their ability to deliver higher average unexpected excess returns.

\subsection{The Dynamics of International Stock Market Excess Returns: Some Final Remarks}

The empirical findings of this chapter can be summarized as follows. First, in contrast to previous empirical findings, the results of this chapter suggest that in the aftermath of equity market liberalizations, emerging stock indexes collapsed (i.e., expected returns increase). Second, it is shown that emerging stock market prices have been largely affected by the crises of the 1990s and early 2000s. Third, de facto integration seems to take 

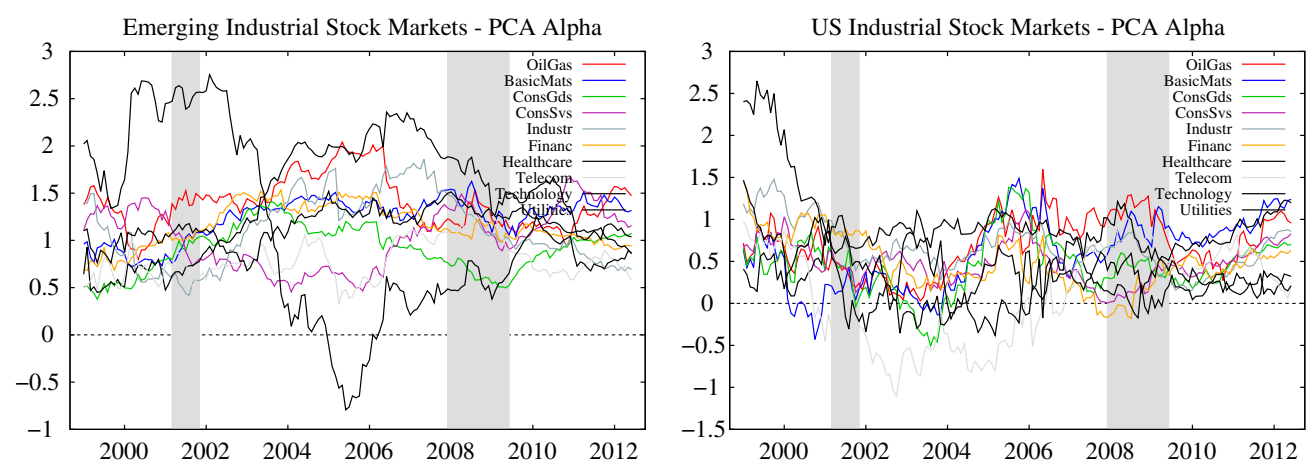

Figure 11 This figure reports the dynamics of the "PCA Alpha" for 10 sectors in the emerging (left panel) and US (right panel) stock markets. Estimates are computed on rolling basis using a window of 60 months. Sample: January 1994 (or later)-June 2012. Note: The shaded vertical bars denote NBERdated recessions.

Source: Based on Donadelli (2013b).

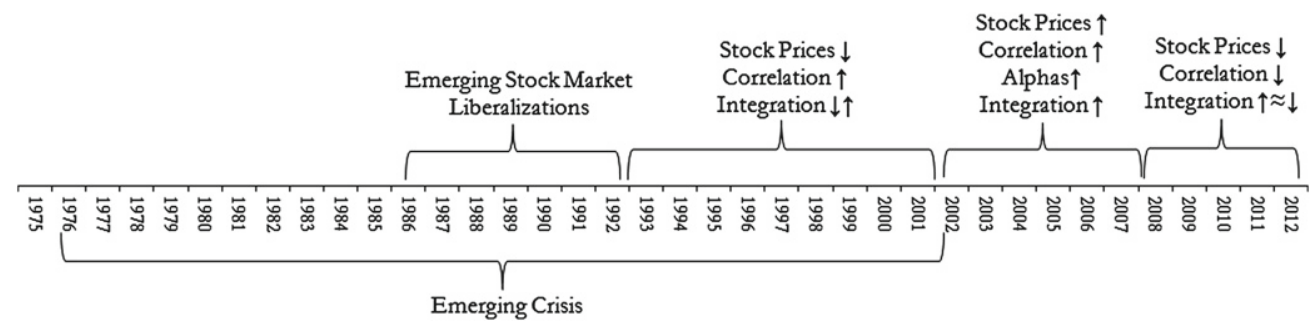

Figure 12 The behavior of emerging stock markets.

Source: Based on Donadelli $(2013 a, b)$.

place between the last two NBER-dated recessions. Fourth, emerging expected returns decrease as de facto integration increases (see Figure 12).

\section{CONCLUSION}

This chapter examines the behavior of international stock market excess returns as well as the impact of real and financial integration on emerging stock market indexes in a time-varying context. Summary statistics confirm that emerging stock markets provide higher average excess returns than advanced stock markets and tend to be highly unstable. Early empirical studies observe that the correlation between emerging and advanced stock market excess returns is very low. As a consequence, long position in emerging equity has provided portfolio diversification benefits for many years. However, as recently documented, the equity market liberalizations of the late 1980s and early 1990s, and the subsequent decrease in the level of segmentation have generated an increase in the 
co-movement between international stock market returns. The impact of liberalizations on emerging stock market prices and the dynamics of the degree of co-movement between international markets have been widely studied. However, most of these studies focus only on stock market country indexes and develop analysis in a static context. In addition they rely on a "contaminated period" (i.e., a period including major emerging crises).

In contrast, this work employs an updated dataset to study the behavior of international stock market excess returns and the impact of de facto integration on emerging stock prices in a dynamic context. The main empirical findings are as follows. First, we observe that emerging stock market indexes have been heavily influenced by domestic shocks. Differently from recent studies that examine the impact of financial market liberalizations on emerging stock excess returns, it is shown that liberalizations have affected expected excess returns (as documented) with some delay. It turns out that financial liberalizations do not necessarily imply de facto integration. Second, using as a measure of financial integration the $\bar{R}^{2}$ of a multi-(artificial) factor model, we observe that international stock market indexes increase, both at the country and sector level, as the level of de facto integration increases. It follows that financial integration seems to be accompanied by economic integration (Phylaktis and Ravazzolo, 2002). Third, it is shown that model's validity is rarely preserved across emerging markets. The latter confirms the emerging markets' ability to generate higher unexpected excess returns. Last, a joint analysis of the dynamics of the co-movement between international stock market returns and the real and financial integration processes indicates that cross-country and cross-industry diversification benefits have largely decreased, thus, forcing international investors to look for alternative forms of investment.

\section{REFERENCES}

Antonakakis, N., Chatziantoniou, I., Filis, G., 2012. Dynamic co-movements between stock market returns and policy uncertainty. Unpublished Working Paper.

Baker, S., Bloom, N., Davis, S., 2012. Measuring economic policy uncertainty. Stanford University, Working Paper Series.

Barry, C., Peavy, J., Rodriguez, M., 1997. Emerging stock markets: risk, return, and performance. Research Foundation of the Institute of Chartered Financial Analysts,

Bekaert, G., Erb, C., Harvey, C.R., Viskanta, T., 1998. Distributional characteristics of emerging market returns and asset allocation. Journal of Portfolio Management, 102-116.

Bekaert, G., Harvey, C.R., Lundblad, C., 2003. Equity market liberalization in emerging markets. Journal of Financial Research 26 (3), 275-299.

Bekaert, G., Harvey, C.R., Lundblad, C., Siegel, S., 2011. What segments equity markets? Review of Financial Studies 24 (12), 3841-3890.

Bilson, C.M., Brailsford, T.J., Hooper, V.J., 2001. Selecting macroeconomic variables as explanatory factors of emerging stock market returns. Pacific-Basin Finance Journal 9 (4), 401-426.

Claessens, S., Dasgupta, S., Glen, J., 1995. Return behavior in emerging stock markets. World Bank Economic Review 9, 131-151.

Corsetti, G., Pericoli, M., Sbracia, M., 2005. Some contagion, some interdependence: more pittfalls in tests of financial contagion. Journal of International Money and Finance 24 (8), 1177-1199. 
de Jong, F., de Roon, F.A., 2005. Time varying market integration and expected returns in emerging markets. Journal of Financial Economics 78, 583-613.

Donadelli, M., 2013a. Global integration and emerging stock market excess returns. Macroeconomics and Finance in Emerging Market Economies.

Donadelli, M., 2013b. On the dynamics of industrial stock market excess returns. CASMEF Working Paper Series No. 2013/02.

Donadelli, M., Lucchetta, M., 2012. Emerging stock premia: do industries matter? DSE Working Paper No. $22 / 12$.

Donadelli, M., Persha, L., 2014. Understanding emerging market equity risk premia: industries, governance and macroeconomic policy uncertainty. Research in International Business and Finance 30, 284-309.

Donadelli, M., Prosperi, L., 2012. On the role of liquidity in emerging markets stock prices. Research in Economics 66 (4), 320-348.

Engle, R., 2002. Dynamic conditional correlation: a simple class of multivariate generalized autoregressive conditional heteroskedasticity models. Journal of Business and Economic Statistics 20 (3), 339-350.

Ferson, W.E., Harvey, C.R., 1994. Sources of risk and expected returns in global equity markets. Journal of Banking and Finance 18, 775-803.

Grootveld, H., Salomons, R., 2003. The equity risk premium: emerging vs. developed markets. Emerging Markets Review 4 (2), 121-144.

Hammond Jr., P.B., Leibowitz, M.L., 2011. In: Hammond Jr., P.B., Leibowitz Jr., M.L., Siegel Jr., L.B. (Eds.), Rethinking the Equity Risk Premium. Research Foundation of CFA Institute.

Harvey, C.R., 1995. The risk exposure of emerging equity markets. The World Bank Economic Review 9 (1), 19-50.

Harvey, C.R., 1995. Predictable risk and returns in emerging markets. Review of Financial Studies 8, 773-816.

Henry, P., 2000. Stock market liberalization, economic reform and emerging market equity prices. Journal of Finance 55, 529-564.

Joyce, J.P., 2011. Financial globalization and banking crises in emerging markets. Open Economies Review $22,875-895$.

Liao, W., Santacreu, A.M., 2012. The trade co-movement puzzle and the margins of international trade. NYU Working Paper.

Mehra, R., Prescott, E.C., 1985. The equity premium: a puzzle. Journal of Monetary Economics 15 (2), 145-161.

Phylaktis, K., Ravazzolo, F., 2002. Measuring financial and economic integration with equity prices in emerging markets. Journal of International Money and Finance 21, 879-903.

Pukthuanthong, K., Roll, R., 2009. Global market integration: an alternative measure and its application. Journal of Financial Economics 92 (2), 214-232.

Santacreu, A.M., 2012. Innovation, diffusion and trade: theory and measurement. INSEAD Working Paper.

Stulz, R.M., 1999a. International portfolio flows and security markets. Dice Center for Financial Economics, The Ohio State University, Working Paper.

Stulz, R.M., 1999b. Globalization and the cost of equity capital. Working Paper, The New York Stock Exchange. 


\title{
Non Print Items
}

\begin{abstract}
:
This chapter studies the behavior of international (i.e., emerging and advanced) stock market excess returns, both at the country and sector level, in a dynamic and globally integrated context. A preliminary analysis confirms that emerging stock markets have compensated international investors with generous excess returns and tend to be highly unstable. In addition, the correlation between international stock market excess returns is increasing over time. Preliminary statistics also suggest that emerging stock market excess returns have been largely influenced by the domestic shocks of the late 1990s and early 2000 s (i.e., emerging crises). In contrast to existing empirical findings, this chapter shows that financial market liberalizations do not necessarily imply economic integration. Using the $\bar{R}^{2}$ of a multi-(artificial) model as a robust measure of financial integration and the trade-to-GDP ratio as a measure of real integration, it is shown that (i) there is a delay between financial market liberalizations and de facto integration; (ii) international stock markets are increasingly integrated; and (iii) average excess returns rise as de facto integration rises. The empirical findings of this chapter might have strong implications for the estimation of the cost of capital and the implementation of international portfolio diversification strategies.
\end{abstract}

\section{Keywords:}

International stock markets, Excess returns, De jure, De facto integration

\section{JEL Classification Codes:}

F15, F36, F44, F62, F65, G01, G15 